\title{
XXVI. New researches on the true nature of the Boetian contractions, especially with reference to the explanation given by $\mathrm{M}$. Chasles
}

\author{
J.O. Halliwell Esq. F.R.S. F.S.A. F.R.A.S.
}

To cite this article: J.O. Halliwell Esq. F.R.S. F.S.A. F.R.A.S. (1840) XXVI. New researches on the true nature of the Boetian contractions, especially with reference to the explanation given by M. Chasles, Philosophical Magazine Series 3, 16:101, 136-138, DOI: $\underline{10.1080 / 14786444008649996}$

To link to this article: http://dx.doi.org/10.1080/14786444008649996

曲 Published online: 01 Jun 2009.

Submit your article to this journal \ulcorner

山 Article views: 1

View related articles 


\section{[ $\begin{array}{ll}136 & ]\end{array}$}

XXVI. Nerw Researches on the true nature of the Boetian Contractions, especially with reference to the Explanation given by M. Chasles. By J. O. Halliwell, Esq., F.R.S., F.S.A., F.R.A.S., \&c.*

I HAVE the pleasure of placing before the readers of the 1 Philosophical Magazine a complete explanation of the first tract in No. 343 of the Arundel MSS. in the British Museum; and that $I$ have been able to accomplish this desideratum affords me the greater gratification, because in so doing I am fulfilling the wish of the patriarch of English Literature†.

The manuscript referred to, sometimes called the Ments Mamuscript, is a small quarto of the twelfth century, on vellum; and the first tract, entitled de Arte Numerandi, consists of four leaves only, unfortunately being imperfect at the end. A fragment from the recto of the first folio is lithographed in the appendix to the Rara Mathematica, which serves to show the style of the manuscript and the forms and names of the contractions.

The treatise itself commences with an explanation of the increasing value of igin, andras, \&c., in the different abacal compartments; in point of fact, a definition of abacal numeration dependent upon the principle of local decimal value. It is important to notice that, after this explanation, the compiler gives the usual definitions of digiti and articuli, clearly showing by that his comprehension of their future value. It is remarkable that everything stated is subservient to multiplication and division, no notice whatever being taken of addition, subtraction, duplation, or mediation;-a plain proof, if any were needed, that when the boundaries were abolished, and when an attempt at a generalization of the local system was made, artificial methods were adopted to come to the same conclusions. Now I would ask M. Libri, or any one who agrees with him, how he can possibly account for such a clumsy, primitive, yet most ingenious, method of avoiding abacal difficulties, if we suppose that the writers of the thirteenth and following centuries derived their arithmetical knowledge direct from the Arabs?

And now for the modus operandi: and in order to render it intelligible to every reader, let us take the first example in multiplication, on account of its great simplicity :-

"Sint ergo iiij. pedes equi, unusquisque habens vj. clavos."

Arbas is to be placed in the lower part of the singular arc

* Communicated by the Author.

+ Hallam's Introduction to the Literature of Europe during the Middle Ages, vol. i. p. 151. 
(arcus singularis), and in the upper part of the same arc is placed chalcus "quasi fundamentum multiplicationis." But in the actual multiplication recourse is had to the common Roman notation, and the result of the multiplication of arbas and chalcus in the singular arc is xxiiij. Then the system of articuli comes into operation, and the articulus of this number (24) is andras, which, by the principle of local position and of no other, is placed in the decenal arc. Now I would ask M. Libri, in reply to every one of his arguments, how can we possibly suppose a rule of this nature with its full explanation to exist, without allowing its author to have possessed the knowledge of the value of local position? The decenal arc is made use of in a simple but masterly manner, and the articulate system is invented to avoid the principal difficulty. The digit arbas, it is almost unnecessary to observe, is placed in the singular arc, and thus we have the complete number represented.

In higher numbers the centenal, millenal, and other arcs come into use. The following rule is a fair specimen of the methods employed :-

"Cum autem per decenum multiplicabis singularem, dices hanc regulam deceni;-Decenus quemcunque arcum multiplicat, in secundo ab eo pone digitum in ulteriori articulum," fol. $2, r^{\circ}$, the reason of which is obvious. Thus, in the MS., the operation for finding the square of twelve is as follows:-
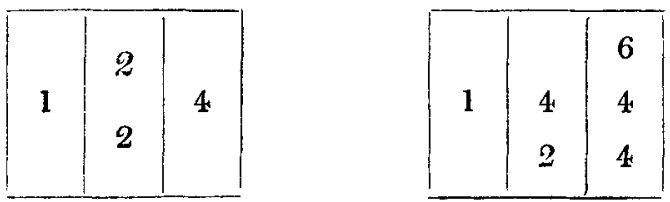

proceeding in a most complicated manner, but merely using the simple formula

$$
m \cdot(n p)=m n p \text {, or, } 12 \times 12=12 \times 2 \times 6=24 \times 6 \text {. }
$$

in which latter case the above rule is applicable. This rule is afterwards generalized.

" His patefactis, oculus mentis aperiatur ad subtilitatem divisionis ;" but as the same system is carried out, precisely similar to the methods of Johannes de Sacro-Bosco, I do not consider it at all necessary to repeat them.

Gerbert uses the Boetian fractional notation*, and I consider this fact a grand argument for his acquaintance with the Boetian contractions, if, indeed, the passage in the geometry

*Pezii Thesaurus, tom. i. pars ii. col. 13. "Quod abacistæ facillimum est." Ibid. col. 30. 
of Boetius was not introduced by him. It does not appear to me that much authority ought to be given to the wellknown passage of William of Malmsbury, ${ }^{*}$ as far as it is supposed to prove that Gerbert brought the knowledge of the abacus from Spain: and, as Professor Peacock† so well observes, "the passage of this historian contains no certain intimation of the knowledge of the notation by nine figures and zero, as the rules which would be thence derived, would tend rather to relieve than increase the labours of the sweating calculators,"-que a sudantibus abacistis vix intelliguntur. Now had the question of the Boetian contractions been broached when Professor Peacock composed his history of arithmetic, he would immediately have seen how evidently this passage refers to them, and this supposition would have explained his doubts in the remaining part of his argument.

In the treatise of Berhelinus in the Bodleian libraryf, the Boetian contractions occur explained by Greck numerals, a most singular and important fact, and one which affords a very strong argument for what $M$. Chasles has stated at $\mathrm{p.} \mathrm{474}$ of his Aperçu Historique. En passant, this is also an argument for the antiquity of this artificial abacal system.

Again, what difference is there between the system of the Greeks, the system in the Mentz Manuscript, the system in the passage in Boetius as satisfactorily explained by $\mathbf{M}$. Chasles, and the Arabic method? I mean with regard to first principless. All, in fact, are contained in the following formula, which is the general expression for any finite number: :-

$$
\mathrm{N}=a_{m} 10^{m}+a_{m-1} 10^{m-1}+a_{m-2} 10^{m-2}+\ldots+a_{1} 10+a_{0},
$$

where $a_{0}, a_{1}, a_{2}, \ldots a_{m}$ are digits, or integers less than the radix 10 .

XXV. On the Permeability of various bodies to the Chemical Rays. By Ronert Hun't.\|

HAVING many years since repeated, with much interest, the experiments of Wedgwood, Davy, and Wollaston on the chemical influence of light, it was with much pleasure

- Wright's Essay on Anglo-Saxon Literature (p.66).

+ History of Arithmetic, p. 415.

I I possess a transcript of this manuscript, but, having mislaid it, am compelled to defer any commentary on it till M. Chasles has published his edition.

\$ M. Chasles, Aperçu Historique, p. 474.

II Communicated by the Author. 